\title{
Genetic Overlap Between ADHD and Autism and Biochemical Factors Affecting It [Letter]
}

\author{
Abdul Moiz Sahito \\ Govinda Khatri \\ Waseem Abbas Abbasi \\ Dow Medical, Karachi, Pakistan
}

Correspondence: Abdul Moiz Sahito; Govinda Khatri

Dow Medical College, Mission Road, New Labour Colony Nanakwara, Karachi, Sindh, Pakistan

Email sahitomoiz@gmail.com; govindakhatri550@gmail.com

\section{Dear editor}

We read a review article entitled "A Review on the Mechanism Between Different Factor and the Occurrence of Autism and ADHD" Xi et al published in Psychology Research and Behavior Management. ${ }^{1}$ We appreciate the authors for this informative review article and would like to make some contributions.

In this review, the authors have specifically elaborated genetic aspects and pathogenic hypotheses of these two kinds of neurodevelopmental diseases in children, autism, and attention deficit hyperactivity disorder (ADHD) while analyzing the relationship between different environmental toxins and these two disorders. ${ }^{1}$

Although, each disorder's individual genetic profile was described the review lacked a mention of the shared genetic overlap between the two disorders and the biochemical factors affecting it. We want to highlight those aspects by mentioning that in a recent study conducted by Ma et al SHANK2 has been shown to be a potential pleiotropic gene underlying the genetic overlap between ADHD and Autism. ${ }^{2}$ It has been suggested that SHANK genes may play a crucial role in memory and executive dysfunctions found in a wide range of neuropsychiatric disorders, including ADHD and Autism Spectrum Disorder (ASD). ${ }^{3}$ There are also some biochemical factors that seem to affect the genes that ADHD and autism share. Recent studies have shown that $\mathrm{Zn}^{2+}$ ions are able to modulate the Postsynaptic Density (PSD) scaffold of synapses via the autism-associated proteins SHANK2 and SHANK3. ${ }^{4}$ Zinc deficiency has also been associated with ADHD. In a study conducted by El-Bakry et al Zinc was found to be significantly deficient in patients with ADHD compared with healthy controls, so it was concluded that zinc deficiency might play a role in the etiopathogenesis of ADHD. ${ }^{5}$

The shared genetic overlap between ADHD and Autism and the biochemical factors that affect that overlap makes it imperative that a thorough study is conducted in this direction to reduce the ambiguity underlying these disorders and to figure out efficient ways to prevent them.

\section{Disclosure}

The authors report no conflicts of interest in this communication.

\section{References}

1. Xi T, Wu J. A review on the mechanism between different factors and the occurrence of autism and ADHD. Psychol Res Behav Manag. 2021;14:393. doi:10.2147/PRBM.S304450 
2. Ma SL, Chen LH, Lee CC, et al. Genetic overlap between attention deficit/hyperactivity disorder and autism spectrum disorder in SHANK2 gene. Front Neurosci. 2021;15:481. doi:10.3389/ fnins.2021.649588

3. Guilmatre A, Huguet G, Delorme R, Bourgeron T. The emerging role of SHANK genes in neuropsychiatric disorders. Dev Neurobiol. 2014;74(2):113-122. doi:10.1002/dneu.22128
4. Jan HH, Chen IT, Tsai YY, Chang YC. Structural role of zinc ions bound to postsynaptic densities. J Neurochem. 2002;83(3):525-534. doi:10.1046/j.1471-4159.2002.01093.x

5. El-Bakry A, El Safty AM, Abdou AA, Amin OR, Ayoub DR, Afifi DY. Zinc deficiency in children with attention-deficit hyperactivity disorder. Egypt $J$ Psychiatr. 2019;40(2):95. doi:10.4103/ejpsy. ejpsy_11_19

Dove Medical Press encourages responsible, free and frank academic debate. The content of the Psychology Research and Behavior Management 'letters to the editor' section does not necessarily represent the views of Dove Medical Press, its officers, agents, employees, related entities or the Psychology Research and Behavior Management editors. While all reasonable steps have been taken to confirm the content of each letter, Dove Medical Press accepts no liability in respect of the content of any letter, nor is it responsible for the content and accuracy of any letter to the editor.

Psychology Research and Behavior Management

Dovepress

\section{Publish your work in this journal}

Psychology Research and Behavior Management is an international, peer-reviewed, open access journal focusing on the science of psychology and its application in behavior management to develop improved outcomes in the clinical, educational, sports and business arenas. Specific topics covered in the journal include: Neuroscience, memory and decision making; Behavior modification and management; Clinical applications; Business and sports performance management; Social and developmental studies; Animal studies. The manuscript management system is completely online and includes a very quick and fair peer-review system, which is all easy to use. Visit http://www. dovepress.com/testimonials.php to read real quotes from published authors. 